\title{
Vitamin D: A Silent Cofactor for Allergic Rhinitis
}

\author{
Rabi Hembrom, ${ }^{1}$ Somnath Patra, ${ }^{1}$ Rupam Sinha, ${ }^{1}$ Indranil Sen, ${ }^{1}$ Satadal Mandal, ${ }^{1}$ Amit Chakrabarti ${ }^{1}$
}

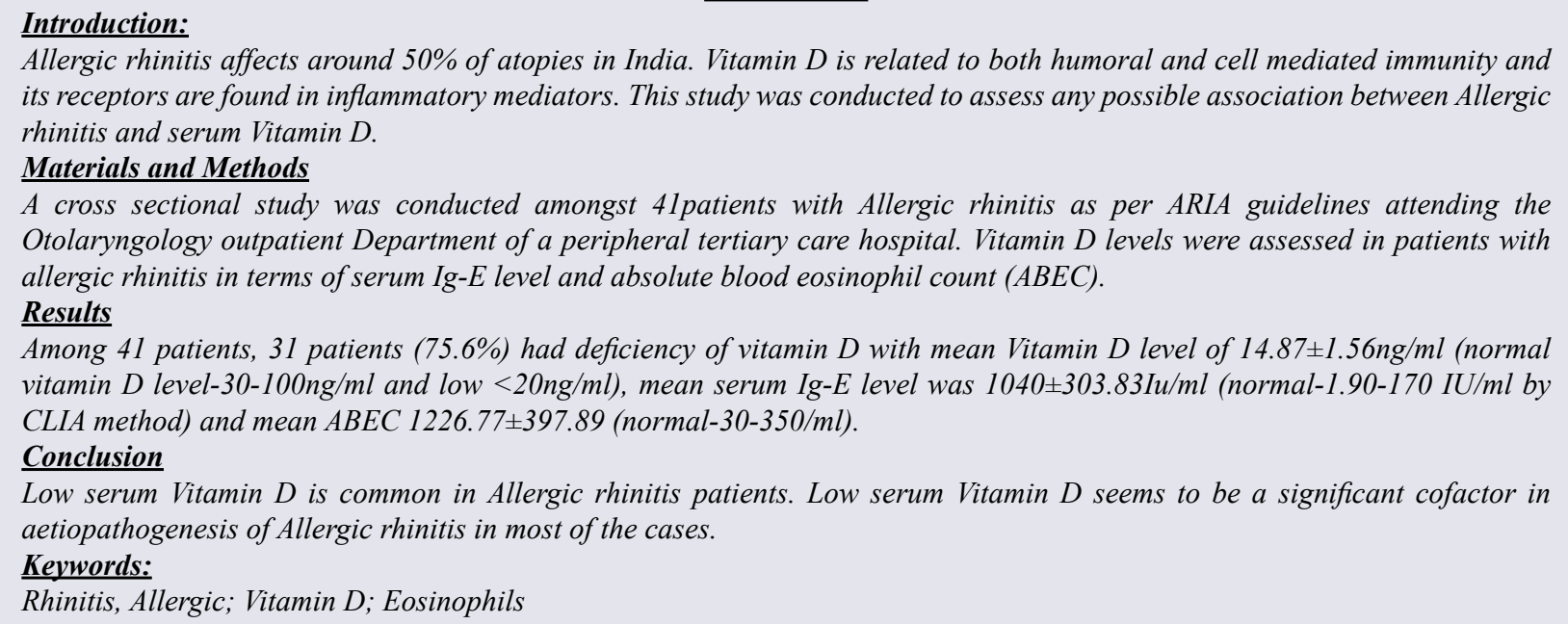

$\mathrm{A}$ llergic rhinitis is one of the commonest chronic conditions with a significant impact on the quality of life. ${ }^{1}$ It has been found that the common symptomatology of allergic rhinitis are nasal congestion, sneezing, nasal itching and rhinorrhea which shows significant overlap with non-allergic rhinitis. ${ }^{2}$ Allergic rhinitis may be seasonal or perennial. Diagnosis is done by history and detailed examination and can be confirmed by skin prick test or estimation of IgE by radio allegro-sorbent test (RAST), enzyme linked immune sorbent assay (ELISA) and blood Eosinophil count.

Vitamin D is a hormone with multiple physiological actions. Vitamin D receptor is expressed in many cell types like T cell, B cell, neutrophil, macrophage. ${ }^{3}$ This

1 - Department of ENT, Midnapore Medical College, Midnapore

\section{Corresponding author:}

Dr Rupam Sinha

email: rupamsinhaad2@gmail.com suggests the role of Vitamin D on immune system. ${ }^{4}$ It has been demonstrated that Vitamin D affects innate and adaptive immune system. In innate immunity Vitamin D inhibits the expression of Toll like Receptor (TLR) on monocyte, inhibits pro-inflammatory cytokine production and induces antimicrobial peptide synthesis. The main source of Vitamin D is solar UV-B (290-315 nm wavelength) which influences the formation of pro-vitamin $\mathrm{D}$ in the skin (cholecalciferol). Cholecalciferol from the skin or that derived from nutrition is metabolized in liver to $25-(\mathrm{OH})$ Vitamin D. This is the major circulating form. Thus it is usually used to measure serum Vitamin D level. 25-(OH) Vitamin D is then transported to kidney where it is metabolized to its active form calcitriol. ${ }^{4,5,6}$

Although threshold of serum 25-(OH) Vitamin D are still debated, guidelines from Institute Of Medicine (IOM) for bone health define "Vitamin D deficiency as serum $25-(\mathrm{OH})$ Vitamin D levels below $30 \mathrm{nmol} / \mathrm{L}$ $(<12 \mathrm{ng} / \mathrm{ml})$ ), while sufficient Vitamin D levels should be considered serum level of at least $50 \mathrm{nml} / \mathrm{L}$ (20ng/ 


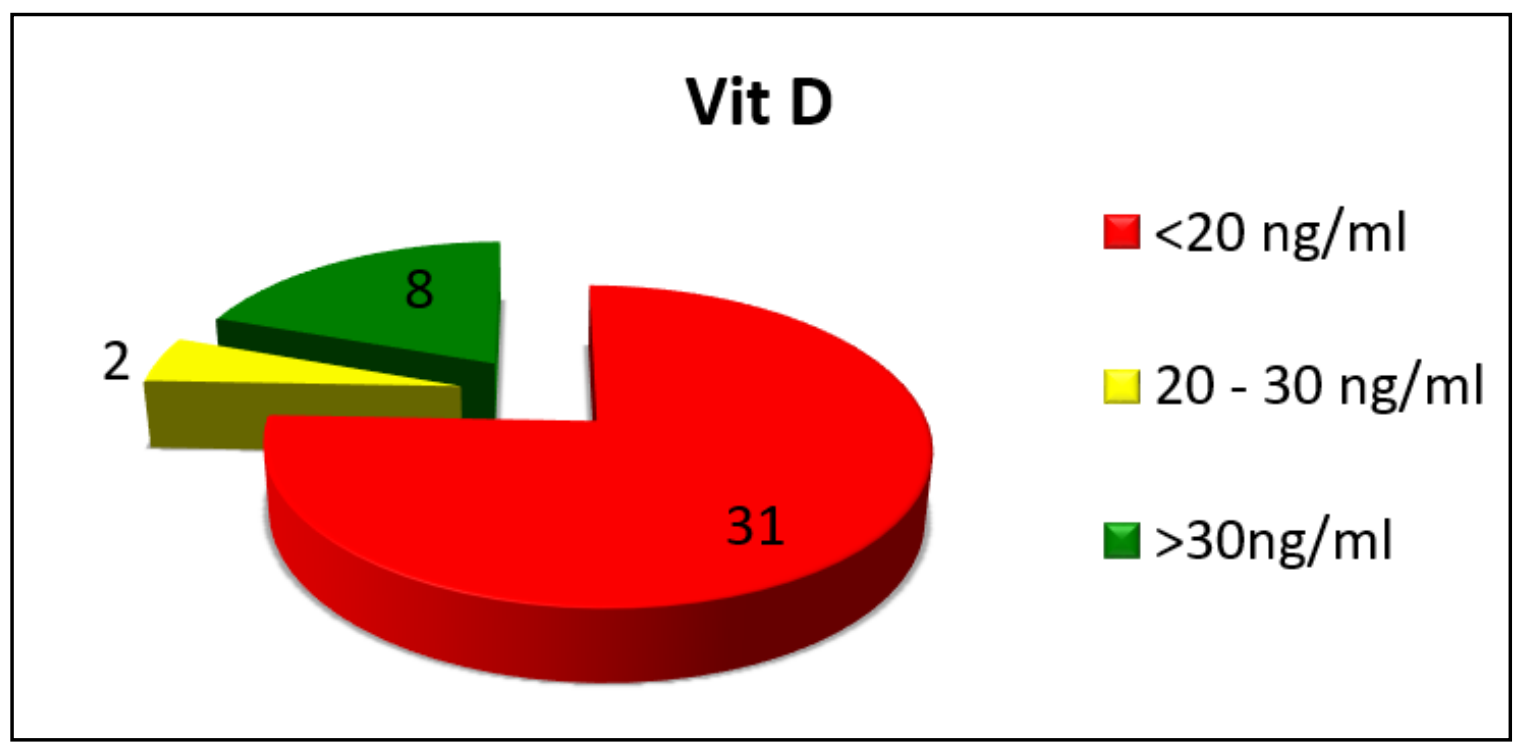

Fig. 1. Pie diagram showing distribution of Vitamin D levels amongst the study subjects

ml). ${ }^{5}$ Due to evidence of Vitamin D insufficiency on allergic disease prevalence, many researchers categorize Vitamin D deficiency as $<75 \mathrm{nmol} / \mathrm{L}(30 \mathrm{ng} / \mathrm{ml}) .{ }^{3}$ This study was conducted to evaluate correlation between Vitamin D level and incidence of Allergic Rhinitis in a group of patients in terms of serum Ig-E level and absolute eosinophil count.

\section{Materials and Methods}

A cross-sectional study was conducted with randomized selection of patients suffering from allergic rhinitis attending the Otolaryngology out-patient department of a peripheral tertiary care institution from January 2016 to October 2017. A Total of 41 patients aged more

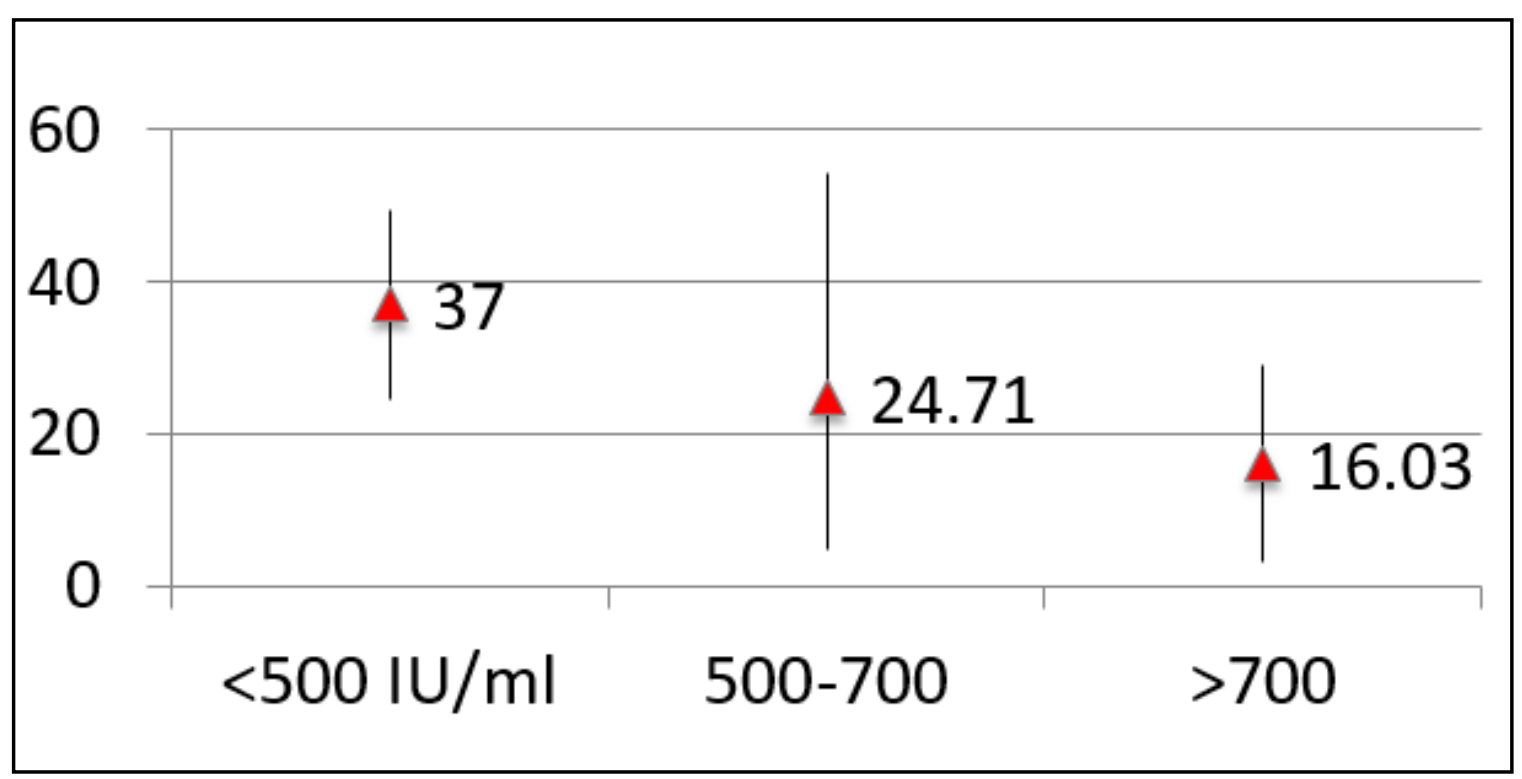

Fig. 2. Comparison between serum (max \& min) Vitamin D (abscissa) \& Serum IgE (ordinate) 


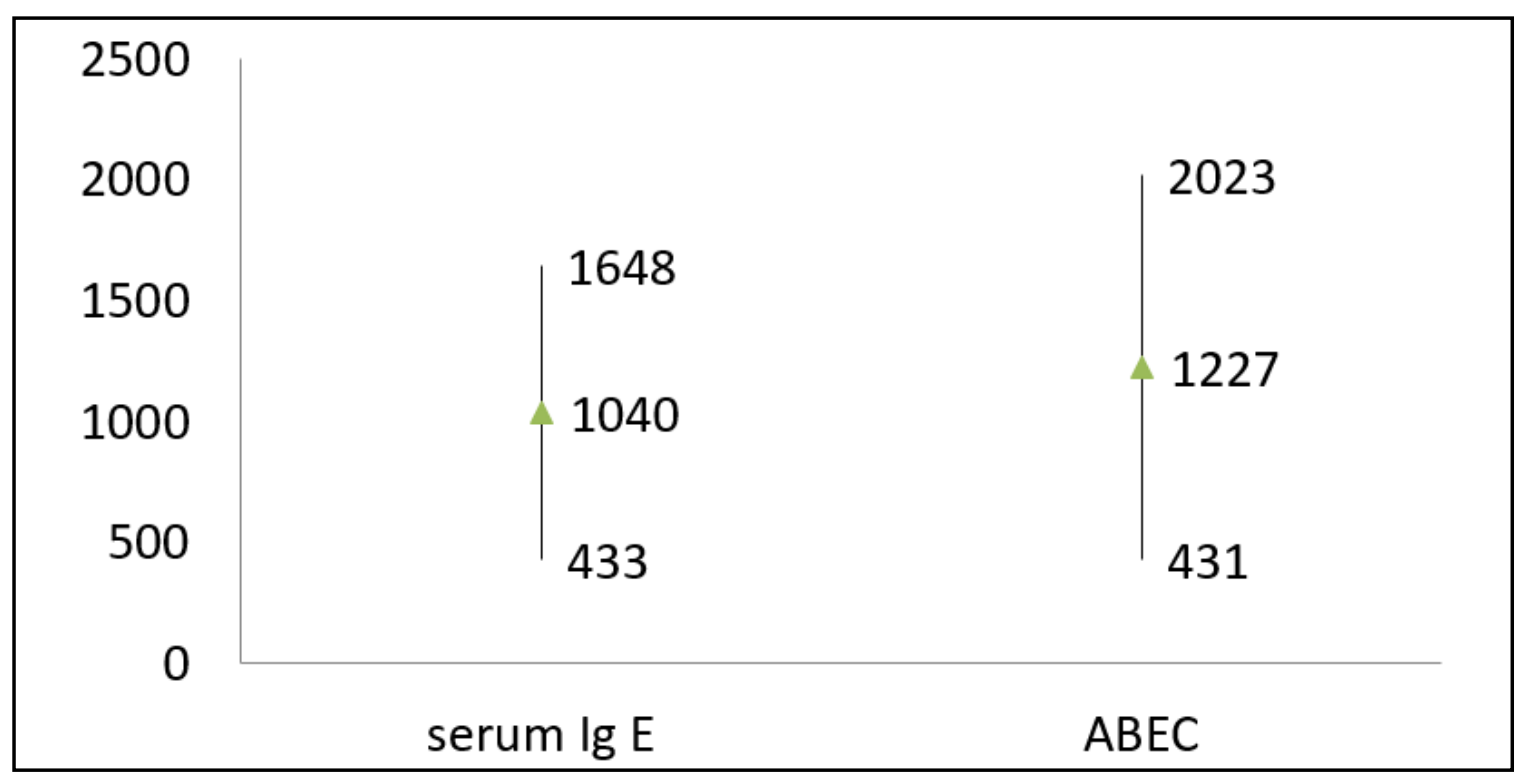

Fig. 3. Stock diagram of IgE level \& ABEC in 31 patients (vitamin $D<20 \mathrm{ng} / \mathrm{ml}$ )

than 11 years were included as per symptoms and signs (ARIA Guideline).

Patients with co-morbid disease that could affect Serum level of Vitamin D e.g. Rheumatoid Arthritis, Cystic Fibrosis, Multiple Sclerosis, Ulcerative Colitis, Crohn's Disease, Celiac Disease, Rickets etc. were excluded from the study. The parameters assessed were Absolute Blood Eosinophil Count (ABEC), serum Ig-E level and serum 25(OH) Vitamin D.

\section{Results}

Out of total 41 patients included in our study, there were 25 males and 16 females with a male: female ratio of $61: 39$. Vitamin D deficiency $(<20 \mathrm{mg} / \mathrm{ml})$ was found in $75.6 \%$ of study population (31 patients). (Fig. 1)

Mean Vitamin D level in deficient cases was 14.87 $\pm 1.56 \mathrm{ng} / \mathrm{ml}$ and mean IgE level was $1040 \pm 303.83 \mathrm{IU} /$ $\mathrm{ml}$ which is elevated considering normal level of IgE up to $170 \mathrm{IU} / \mathrm{ml}$. Mean ABEC was $1226.77 \pm 397.89 / \mathrm{ml}$ assuming normal Eosinophil count 350/ml.

$\mathrm{P}$ value was $<0.0001$ between $\operatorname{IgE}$ and Vitamin D.(Fig.2) $\mathrm{P}$ value was also $<0.0001$ in $\mathrm{ABEC}$ and Vitamin D. (Fig.3)

\section{Discussion}

This study sought to detect the incidence of vitamin D insufficiency (serum $25(\mathrm{OH})$ vitamin D calcidiol) among 41 patients of allergic rhinitis and to correlate the relation between vitamin $\mathrm{D}$ level, serum IgE and ABEC. The study showed that $75.6 \%$ of the patients had vitamin $\mathrm{D}$ deficiency. The mean value of $25(\mathrm{OH})$ vitamin $\mathrm{D}$ was significantly lower in allergic rhinitis patients.

In the present study, the mean level of Vitamin D is $14.87 \pm 1.56 \mathrm{ng} / \mathrm{ml}$. There are other studies in the available literature recently coming in support of this fact as stated by Arshi et al. ${ }^{8}$ The prevalence of severe Vitamin D deficiency was significantly higher in patients with Allergic rhinitis than normal population. ${ }^{9}$ According to Halonen et al. ${ }^{10}$ a significant relationship exists between serum IgE levels and eosinophilia presumed to be free of parasites where IgE levels presumably provide a better clue to atopy than do skin test. Kose et al. showed majority of Allergic rhinitis had Vitamin D deficiency and the mean level was $14.7 \mathrm{ng} / \mathrm{ml} .{ }^{11}$ Jung et al. found association between low Vitamin D level (mean 16.71ng/ $\mathrm{ml}$ ) and Allergic rhinitis prevalence. ${ }^{12}$ Modh et al. in his study also found correlation between serum Vitamin D (mean value $18.03 \pm 5.61$ ) and Allergic rhinitis. ${ }^{9}$

But in a large review by Ghaffari et al. it is found two 


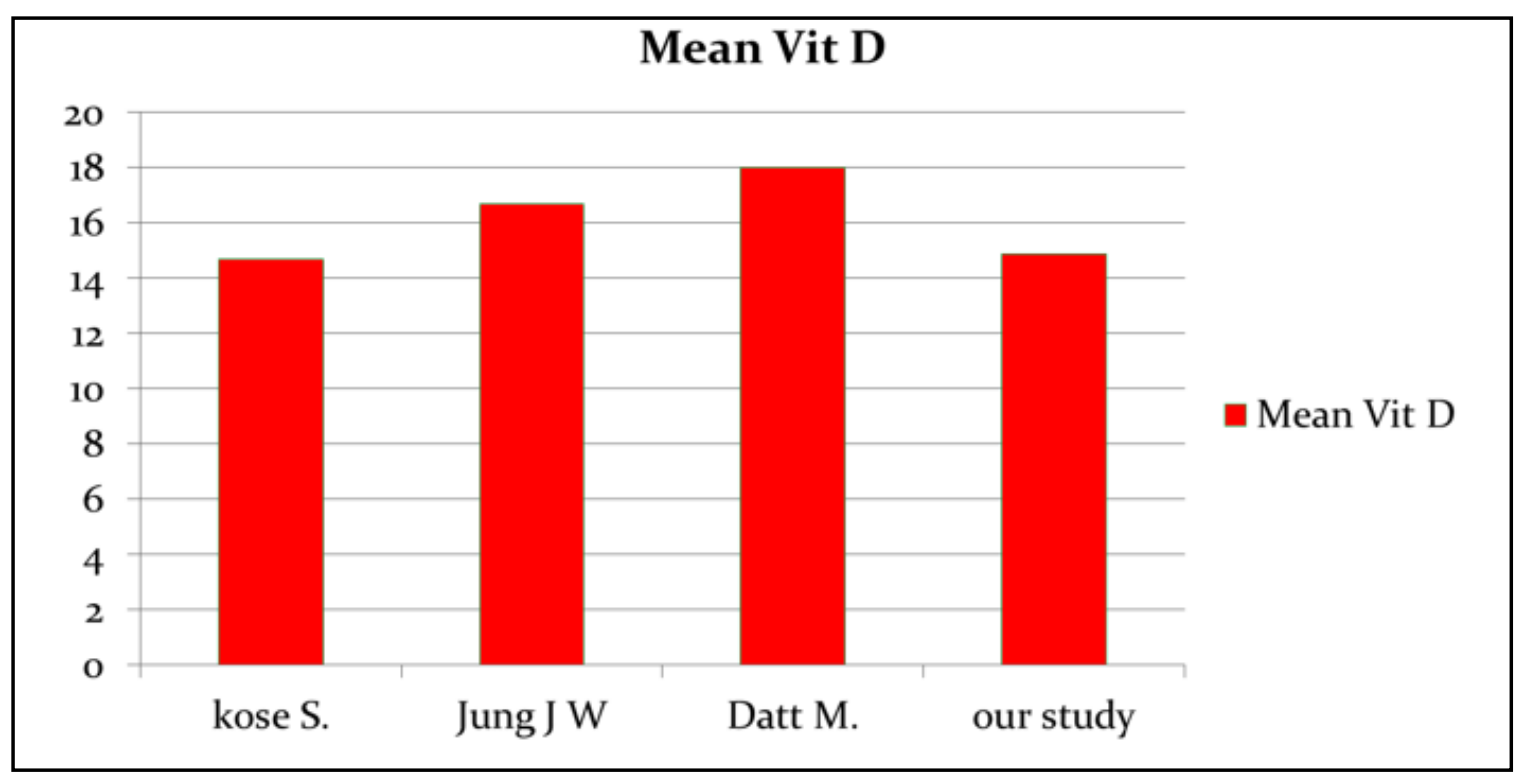

Fig. 4. Comparison of mean Vitamin D level in different studies

third of the reviewed studies show a correlation between serum level of vit $\mathrm{D}$ and Allergic rhinitis. ${ }^{13}$ Cheng et al. showed no correlation between Allergic rhinitis and vitamin D deficiency. ${ }^{14}$ (Fig. 4)

The improvement in the allergic status can be attributed to the immune-modulator effects of vitamin D on the immune system: Vitamin D regulates the activity of various immune cells, including monocytes, dendritic cells, T and B lymphocytes, as well as immune functions of epithelialcells. ${ }^{4}$ Furthermore, some immune cells express vitamin $\mathrm{D}$ activating enzymes facilitating local conversion of inactive vitamin $\mathrm{D}$ into active calcitriol with subsequent paracrine and autocrine effects. ${ }^{15,16}$ As $25(\mathrm{OH})$ vitamin D serum levels are low in individuals and vitamin $\mathrm{D}$ influences allergy mediating immune cells such as T-cells and immune functions of cells forming the barriers against allergies such as epithelial cells, one might speculate that vitamin D plays a role in allergy development. First scientist who hypothesized a link between nutritional intake of vitamin D and allergies were Wjst and Dold in 1999. ${ }^{17}$

Effect of vitamin D on innate immunity: Innate immune responses comprise all mechanisms that resist infection, but do not require specific recognition of the pathogen. Several aspects of innate immunity are affected by vitamin D. The expression of pattern recognition receptor, which activates innate immune responses such as Toll-like receptors (TLRs) on monocytes are inhibited by Vitamin D, which leads to suppression of TLR-mediated inflammation. ${ }^{6}$ Vitamin D induces autophagy in human macrophages, which helps in the defense against opportunistic infections. ${ }^{18}$ The endogenous antimicrobial peptide in resident epithelial cells in the skin and lung are induced by Vitamin D, thereby strengthening the innate barriers against environmental allergens. ${ }^{19,20}$

Effect of vitamin D on adaptive immunity: Lymphocytes such as T-cell with Th1 and Th2 polarization are major players in adaptive immunity and vitamin $\mathrm{D}$ modulates their functions. Pro-inflammatory cytokine release from peripheral mononuclear blood cells in general and from T-cells in particular are decreased by vitamin D. ${ }^{21,22}$ In addition, T-cell proliferation is suppressed by vitamin $\mathrm{D}$ through decreased Th1 cytokine production. ${ }^{23}$ Vitamin D increases IL-10 and decreases IL-2 production, thereby promoting the state of hypo-responsiveness in $\mathrm{T}$ regulatory cells - an effect which is also seen with anti-allergic therapies such as corticosteroids or allergen immunotherapy. ${ }^{23}$

Effect of vitamin D on IgE secretion, mast cells and eosinophils: Vitamin D also affects B lymphocytes functions and modulates the humoral immune response 
including secretion of IgE. ${ }^{24}$ Allergy-mediating cells such as mast cells and eosinophils are also targets of vitamin D. Increased cutaneous vitamin D synthesis increases IL-10 production in mast cells, which leads to suppression of skin inflammation. ${ }^{25}$ Vitamin D treated mice showed reduced airway hyper-responsiveness and decreased infiltration of eosinophils in the lungs. ${ }^{26}$

\section{Conclusion}

Measurement of serum vitamin D level could be helpful in routine assessment of patients with allergic rhinitis. Supplementation of Vitamin D might alter the natural course of disease, leading to significant clinical outcome and perhaps reduce the morbidity of the patient. Hopefully, Vitamin D supplementation may also reduce intranasal corticosteroid related side effects.

\section{References}

1. Skoner DP. Allergic rhinitis: Definition, epidemiology, pathophysiology, detection, and diagnosis. J Allergy Clin Immunol. 2001 Jul;108(1 Suppl):S2-8

2. Bachert C. Persistent Rhinitis - Allergy or Non-allergy? Allergy. 2004; 59 Suppl 76:11-5; discussion 15

3. Holick MF. Vitamin D deficiency. N Engl J Med. 2007; 357:266-81

4. Hewison M. Vitamin D and Innate and Adaptive immunity. Vitam Horm. 2011; 86:23-62

5. Ross AC, Manson JE, Abrams SA, Aloia JF, et al. The 2011 report on diatery reference intake for calcium and Vitamin D from Institute of Medicine; what clinicians need to know. J Clin Endocrinol Metab. 2011 Jan; 96(1):53-8

6. Sadeghi K, Wessner B, Laggner U, Ploder M, et al. Vitamin D down regulates Monocyte TLR expression and triggers hypo responsiveness to pathogen associated molecular pattern. Eur J Immunol. $2006 \mathrm{Feb}$; 36(2):361-70

7. Wittig HJ, Belloit J, De Fillippi I, Royal G. Age-related serum immunoglobulin E levels in healthy subjects and in patients with allergic disease. J Allergy Clin Immunol. 1980 Oct; 66(4):305-13

8. Arshi S, Ghalehbaghi B, Kamrava SK, Aminlou M. Vitamin D serum levels in Allergic rhinitis: any difference from normal population? Asia Pac Allergy 2012 Jan; 2(1):45-8

9. Modh D, Katarkar A, Thakkar B, Jain A, et al. Role of vitamin D supplementation in allergic rhinitis. Indian Journal of Allergy, Asthma and Immunology 2014; 28(1):35-9
10. Halonen M, Barbee RA, Lebowitz MD, Burrows B. An epidemiologic study of the interrelationships of total serum immunoglobulin E, allergy skin-test reactivity, and Eosinophilia. The Journal of allergy and clinical immunology1982; 69(2):221-8

11. Kose S, Senger SS, Yalcin AD, Serin BG, Cavdar G. Vitamin D serum levels in allergic rhinitis.. World Allergy Organization Journal 2015; 8:579

12. Jung JW, Kim JY, Cho SH, Choi BW, Min KU, Kang HR. Allergic rhinitis and serum 25-hydroxyvitamin D level in Korean adults. Ann Allergy Asthma Immunol. 2013 Nov; 111(5):352-7

13. Ghaffari J, Ranjbar A, Quade A. Vitamin D Deficiency and Allergic Rhinitis in Children: A Narrative Review. J Pediatr Rev. 2015; 3(2):e2623

14. Cheng HM, Kim S, Park GH, Chang SE, Bang S, Won CH, Lee $\mathrm{MW}$, Choi JH, Moon KC. Low vitamin D levels are associated with atopic dermatitis, but not allergic rhinitis, asthma, or IgE sensitization, in the adult Korean population. J Allergy Clin Immunol. 2014 Apr;133(4):1048-55

15. Baeke F, Takiishi T, Korf H, Gysemans C, Mathieu C. Vitamin D: Modulator of the immune system. Curr Opin Pharmacol. 2010 Aug; 10(4):482-96

16. Akbar NA, Zacharek MA. Vitamin D: immunomodulation of asthma, allergic rhinitis, and chronic rhinosinusitis. Curr Opin Otolaryngol Head Neck Surg. 2011 Jun;19(3):224-8

17. Wjst M, Dold S. Genes, factor X, and allergens: What causes allergic diseases? Allergy 1999; 54(7):757-9

18. Campbell GR, Spector SA. Hormonally active vitamin D3 (1alpha,25-dihydroxycholecalciferol) triggers autophagy in human macrophages that inhibits HIV-1 infection. J Biol Chem. 2011 May 27; 286(21):18890-902

19. Schauber J, Dorschner RA, Yamasaki K, Brouha B, Gallo RL. Control of the innate epithelial antimicrobial response is celltype specific and dependent on relevant microenvironmental stimuli. Immunology 2006 Aug;118(4):509-19

20. Gorman S, Judge MA, Hart PH. Immune-modifying properties of topical vitamin D: Focus on dendritic cells and T cells. J Steroid Biochem Mol Biol. 2010 Jul;121(1-2):247-9

21. Khoo AL, Chai LY, Koenen HJ, Sweep FC, Joosten I, Netea $\mathrm{MG}$, van der Ven AJ. Regulation of cytokine responses by seasonality of vitamin D status in healthy individuals. Clin Exp Immunol. 2011 Apr;164(1):72-9

22. Muthian G, Raikwar HP, Rajasingh J, Bright JJ. 1,25 Dihydroxyvitamin-D3 modulates JAK-STAT pathway in IL12/IFNgamma axis leading to Th1 response in experimental allergic encephalomyelitis. J Neurosci Res. 2006 May 15; 83(7):1299-309

23. Robinson DS. Regulatory T cells and asthma. Clin Exp Allergy. 2009 Sep;39(9):1314-23

24. Hartmann B, Heine G, Babina M, Steinmeyer A, et al. Targeting the vitamin $\mathrm{D}$ receptor inhibits the $\mathrm{B}$ cell-dependent allergic 
immune response. Allergy 2011 Apr;66(4):540-8

25. Biggs L, Yu C, Fedoric B, Lopez AF, Galli SJ, Grimbaldeston MA. Evidence that vitamin $\mathrm{D}(3)$ promotes mast cell-dependent reduction of chronic UVB-induced skin pathology in mice. $\mathrm{J}$ Exp Med. 2010 Mar 15; 207(3):455-63
26. Gorman S1, Judge MA, Burchell JT, Turner DJ, Hart PH. 1,25-dihydroxyvitamin D3 enhances the ability of transferred CD4+ CD25+ cells to modulate $\mathrm{T}$ helper type 2-driven asthmatic responses. Immunology 2010 Jun;130(2):181-92. 